\title{
Only Follow-Up of Memory B Cells Helps Monitor Rituximab Administration to Patients with Neuromyelitis Optica Spectrum Disorders
}

\author{
Christine Lebrun - Mikael Cohen • Maria Alessandra Rosenthal-Allieri • \\ Saskia Bresch • Sylvia Benzaken - Romain Marignier • Barbara Seitz-Polski • \\ Michel Ticchioni
}

Received: May 2, 2018 / Published online: June 7, 2018

(C) The Author(s) 2018

\section{ABSTRACT}

Introduction: Neuromyelitis optica spectrum disorders (NMOSD) are identified as a spectrum of inflammatory demyelinating disorders involving the brain, spinal cord and optic nerves. These disorders require early diagnosis

Enhanced digital content To view enhanced digital content for this article go to https://doi.org/10.6084/ m9.figshare.6392279.

Authors Barbara Seitz-Polski and Michel Ticchioni participated equally to the research.

C. Lebrun $(\varangle) \cdot$ M. Cohen $\cdot$ S. Bresch

Centre de Ressources et Compétences sclérose en plaques, Neurologie, Université Nice Côte d'Azur, CHU Pasteur 2, Nice, France

e-mail: Lebrun.c@chu-nice.fr

M. A. Rosenthal-Allieri · S. Benzaken · B. Seitz-Polski - M. Ticchioni

Laboratoire d'Immunologie, CHU Archet 1, Nice, France

R. Marignier

Sclérose en plaques, pathologies de la myéline et neuro-inflammation, Hospices Civils de Lyon, Lyon, France

R. Marignier

France-Centre de Recherche en Neurosciences de Lyon, Inserm U1028 CNRS UMR5292, FLUID team, Faculté de Médecine Laennec, Lyon, France

M. Ticchioni

Centre Méditerranéen de Médecine Moléculaire,

INSERM U1065, Nice, France and highly active immunosuppressive treatment. Rituximab (RTX) has demonstrated efficacy in limiting relapse in NMOSD when using several administration schedules. We questioned if the CD19+CD27+ memory B cell count was a more reliable marker to monitor RTX administration than the RTX plasma level and CD19+ B cell count.

Methods: We analyzed 125 blood samples from 17 NMOSD patients treated with RTX and also measured the level of anti-aquaporine- 4 antibodies (anti-AQP-4 Abs), human anti-chimeric antibodies to the murine fragment of RTX (HACA-RTX Abs), and the RTX concentration.

Results: The mean follow-up time of the cohort was 7.4 (2-16) years. All patients improved with a mean EDSS going from 4 (1-8.5) to 2.7 (1-5.5). The mean interval between RTX infusions was 9.6 months with identification of prolonged responders. Total CD19+ B cell detection with the routine technique did not correlate to reemergence of CD19+ CD27+ memory B cells. The RTX residual concentration did not correlate with the CD19+ CD27+ memory B cell count or with anti-RTX antibody production.

Conclusion: In contrast to total CD19+ cell, detected with the routine technique, CD19+ CD27+ memory $\mathrm{B}$ cells are a reliable marker for biological relapse and allow a decrease in the frequency of infusions. 
Keywords: Efficacy; Memory B cells; Neuromyelitis optica spectrum disorder; Safety; Rituximab

\section{INTRODUCTION}

Neuromyelitis optica spectrum disorders (NMOSD) are defined as rare inflammatory demyelinating disorders of the central nervous system, involving mostly the spinal cord and optic nerves. Since initial description by Eugene Devic and Fernand Gault, many versions of the diagnostic criteria have been published and recently updated $[1,2]$. Since their discovery by Dr. Lennon in 2004, evaluation of the positivity to anti-aquaporin 4 antibodies (anti-AQP4 Abs) is a rapid way to confirm diagnosis [3]. For seronegative patients, the recent clinical-radiological criteria may define them as NMOSD, according to the presence of specific clinical criteria including transverse myelitis and optic neuritis. There is no treatment consensus but it should be given as early as possible, after the first attack if the patient meets the diagnostic criteria [4]. Today, a large number of retrospective studies suggest that a drug targeting B cells, and specifically rituximab (RTX), is to be considered as a first-line option $[5,6]$ or in rescue after oral immunosuppressants [7-9].

Rituximab (MabThera ${ }^{\circledR}, \operatorname{Rituxan}^{\circledR}$ ) is a chimeric monoclonal antibody (mAb) against CD20, a human B-lymphocyte antigen. Our aim was to define the usefulness of all available routine biomarkers in monitoring RTX administration in the clinical management of NMOSD patients. In the present study, we investigated longitudinally during the follow-up of 17 NMOSD patients the detection of AQP4-Abs, the RTX concentration, anti-drug antibodies and flow cytometric measurement of total and memory B cells using both a routine test (total B cells) and a minimal residual disease (MDR) derived-test (total B cells and memory B cells).

\section{METHODS}

\section{Clinical Assessment}

This is an observational case series study in which 17 NMOSD patients were evaluated and clinically assessed. Patients were diagnosed according to the 2006 Wingerchuk diagnostic criteria [10] and treated in the MS Clinic in Nice (CRCSEP), France. Clinical charts were reviewed for demographic data (age, body mass index, comorbidities), clinical course, RTX infusion tolerance, relapse (annual relapse rate: ARR), and Expanded Disability Status Scale (EDSS) every 3 months. A total of 125 NMOSD patient blood samples were analyzed for the anti-AQP4 serostatus, CD19 cell testing, RTX concentrations, and anti-drug Abs (human anti-chimeric antibodies to the murine fragments of RTX (HACA-RTX Abs).

\section{Treatment Schedule}

After extensive biological screening (hematology, virology, renal and hepatic functions), patients were treated with RTX consisting of infusion of $1 \mathrm{~g}, 2$ weeks apart. Blood samples were collected from the 17 patients with NMOSD before the injection of RTX (week 0), and then every 3 months until re-emergence of CD19+ CD27+ memory B cells or in case of a clinical event. When CD19+ CD27+ memory B cells were considered positive ( $>0.05 \%$ of total leucocytes count), infusion (rituximab, $1 \mathrm{~g} \mathrm{~d} 1$ ) was maintained. Reactions of intolerance or adverse events were reported. The MS nurses, using a structured format [graded according to Common Terminology Criteria for Adverse Events (CTCAE) v. 4.03] collected information about intolerance and adverse events related to infusion.

\section{Indirect Immunofluorescence (IFI) Cell- Based Assay (CBA) for AQP4-Ab and MOG- Ab Detection}

AQP4-Abs were assessed using a CBA including HEK293 cells stably transfected with human M23-AQP4 as previously described [11]. 
Multicolor Flow Cytometry (MFC) Analysis of Circulating B Cells and Their Sub-Populations

Flow cytometric analysis was performed on blood collected on EDTA and labeled within $24 \mathrm{~h}$. The percentage and absolute count of B, T and NK cells were determined using the $\mathrm{BD}$ Multitest ${ }^{\mathrm{TM}}$ 6-color TBNK reagent and BD Trucount $^{\mathrm{TM}}$ tubes (BD Biosiences). For MRDderived MFC, cells were labeled with a 8-color mixture of antibodies (CD38, CD45; CD27; anti-IgD; CD24; anti-IgM; CD3; CD14, CD19) allowing identification of all $\mathrm{B}$ cells and of at least 6 different $B$ cell sub-populations namely naïve $B$ cells $\left(C D 27^{\text {neg }}, \operatorname{IgD}^{+}, \operatorname{IgM}^{+}\right)$, switched memory B cells $\left(\mathrm{CD}_{27^{+}}, \mathrm{IgD}^{\text {neg }}, \mathrm{IgM}^{\text {neg }}\right)$, marginal zone like memory $\mathrm{B}$ cells $\left(\mathrm{CD} 27^{+}, \mathrm{IgD}^{+}\right.$, $\left.\operatorname{IgM}^{+}\right), \mathrm{CD} 27$ negative memory B cells $\left(\mathrm{CD} 27^{\text {neg }}\right.$, $\left.\mathrm{IgD}^{\text {neg }}, \mathrm{IgM}^{\text {neg }}\right)$, transitional B cells $\left(\mathrm{CD} 24^{+}\right.$, $\left.\mathrm{CD} 38^{++}\right)$and plasmablasts $\left(\mathrm{CD} 24^{\text {neg }}, \mathrm{CD} 38^{++}\right)$. Results were expressed as the percentage of the different B cell populations in the white blood cells (WBC) population. CD19+ CD27+ memory $\mathrm{B}$ cells were considered as present if more than 25 cells were detected, but positive for treatment if $>0.05 \%$ of the total leucocytes count.

Measure of Rituximab Concentrations (ELISA) Anti-RTX Abs were coated according to the manufacturer's instructions (LISA-TRACKER Duo Rituximab, Theradiag $\odot$ Croissy Beaubourg, France) as previously described [12]. The limit of detection of RTX was $2 \mu \mathrm{g} / \mathrm{mL}$ with an intra-run variability of $7.6 \%$ and inter-run variability of $9.8 \%$.

\section{HACA RTX Antibody Determination}

Anti-RTX Abs were evaluated by ELISA, with neutralization of RTX with anti-RTX-Abs in vitro as previously described [13], and with an antibody-dependent, complement-independent cell cytotoxicity assay. HACA RTX Abs were reported as negative (0) when detected (0 to $<10 \mathrm{ng} / \mathrm{mL}$ ) and positive (titer $>10 \mathrm{ng} / \mathrm{mL}$ ).

\section{Statistical Analysis}

Qualitative variables were expressed as frequencies and compared using the Fisher exact test. Continuous variables were expressed as median and interquartile intervals and compared using the Student's $t$ test. Comparisons of qualitative variables were performed using the Fisher exact test. Quantitative variables were compared using the Wilcoxon-Mann-Whitney or Kruskall Wallis test for multilevel variables. Correlation between the residual serum RTX levels, the total CD19 cell count and memory B cells counts were assessed with the Spearman rank correlation coefficient. All tests were twosided, and a $p$ value less than 0.05 indicated statistical significance. Analyses were performed using SAS V.9.3 software (SAS Institute, Cary, NC, USA).

This article is based on previously conducted studies and does not contain any studies with human participants or animals performed by any of the authors.

\section{RESULTS}

\section{Demographic Characteristics and Clinical Evolution}

The disease followed a typical optico-spinal relapsing course in all patients. The demographic characteristics are summarized in Table 1. Patient characteristics were: women $12 / 17$, mean age at diagnosis: $36(22-52)$ years. Nine patients had anti-AQP4 Abs. Ten patients had previous disease-modifying treatments (azathioprine: 7, mycophenolate mofetil: 1, plasma exchange: 2 ). None had orally administered corticosteroids in add-on therapy except when relapse occurred before RTX therapy; seven patients were treated with RTX as firstline treatment. Immunosuppressive agents were discontinued when RTX was introduced. The mean follow-up of the patients was $7.4(2-16)$ years with a mean duration of the disease after starting RTX of 38 (3-41) months. There was no demographic difference between patients with or without anti-AQP4 Abs. The mean clinical relapse before RTX induction was $3.1(1-6)$ 
Table 1 Demographic characteristics of the NMOSD patients

\begin{tabular}{|c|c|c|c|c|c|c|c|c|}
\hline ID & Gender & $\begin{array}{l}\text { Age at } \\
\text { diagnosis } \\
\text { (years) }\end{array}$ & $\begin{array}{l}\text { AQP4 } \\
\text { status }\end{array}$ & $\begin{array}{l}\text { Relapse } \\
\text { before } \\
\text { RTX }\end{array}$ & $\begin{array}{l}\text { Treatment } \\
\text { before } \\
\text { rituximab }\end{array}$ & $\begin{array}{l}\text { EDSS at } \\
\text { rituximab } \\
\text { induction }\end{array}$ & $\begin{array}{l}\text { Total } \\
\text { Follow-Up } \\
\text { (years) }\end{array}$ & $\begin{array}{l}\text { Last } \\
\text { EDSS }\end{array}$ \\
\hline $1 \mathrm{AM}$ & $\mathrm{F}$ & 52 & Positive & 1 & - & 6 & 3.5 & 3.5 \\
\hline $2 \mathrm{BG}$ & $\mathrm{F}$ & 31 & Positive & 3 & - & 4 & 6.5 & 3 \\
\hline $3 \mathrm{CF}$ & $\mathrm{F}$ & 27 & Positive & 1 & Plasma exchange & 8.5 & 3.5 & 3.5 \\
\hline $4 \mathrm{CP}$ & $\mathrm{F}$ & 32 & Positive & 5 & Plasma exchange & 7.5 & 8 & 1 \\
\hline $5 \mathrm{NY}$ & M & 22 & Positive & 4 & Azathioprine & 2 & 8 & 0 \\
\hline $6 \mathrm{PN}$ & M & 22 & Positive & 6 & Mycophenolate & 4 & 16 & 3.5 \\
\hline 7 TMJ & $\mathrm{F}$ & 44 & Positive & 3 & Azathioprine & 5 & 10 & 2 \\
\hline 8 SFA & $\mathrm{F}$ & 40 & Positive & 2 & Azathioprine & 6 & 7 & 6 \\
\hline 9 AS & $\mathrm{F}$ & 39 & Positive & 3 & - & 5 & 11 & 2 \\
\hline $\begin{array}{l}10 \\
\mathrm{CM}\end{array}$ & $\mathrm{F}$ & 34 & Negative & 2 & Azathioprine & 4 & 6 & 4 \\
\hline $\begin{array}{l}11 \\
\text { DO }\end{array}$ & $\mathrm{F}$ & 38 & Negative & 2 & - & 4 & 6 & 4 \\
\hline $12 \mathrm{VE}$ & M & 40 & Negative & 2 & Azathioprine & 3.5 & 2 & 3 \\
\hline 13 OS & $\mathrm{F}$ & 34 & Negative & 1 & - & 4 & 2 & 1 \\
\hline $14 \mathrm{BM}$ & M & 31 & Negative & 3 & Azathioprine & 6.5 & 6 & 4.5 \\
\hline 15 SG & M & 26 & Negative & 5 & - & 1 & 16 & 0 \\
\hline $16 \mathrm{SN}$ & $\mathrm{F}$ & 33 & Negative & 3 & Azathioprine & 1 & 12 & 1 \\
\hline 17 GS & $\mathrm{F}$ & 52 & Negative & 2 & - & 3.5 & 2.5 & 5.5 \\
\hline
\end{tabular}

months with a median EDSS of 4 (1-8.5) on RTX induction. No patient developed clinical relapse after RTX therapy. The mean follow-up of the patients on RTX was $3.2(1.6-5.7)$ years. At 1 and 2 years of follow-up, all patients improved with a median EDSS of 3 (1-5.5). A total of 62 RTX infusions were administered (mean 3.4 infusions/patient; range 2-6 infusions/patient). The mean interval between RTX infusions for seropositive patients was $9.6(6-20)$ months (Table 2) with 1.1 infusions per year (0-2) compared with four infusions in the standardized schedule.

\section{Anti-AQP4 Abs Detection}

For nine patients, anti-AQP4 Abs were positive and remained positive at follow-up. All the patients were negative for MOG antibodies.

\section{B Cell Repopulation}

Patients were treated when CD19+ CD27+ memory B cells re-emerge quickly near $0.05 \%$ of $\mathrm{WBC}$; this situation is defined as biological relapse (Fig. 1a, row 3). None of the patients had a clinical attack with prior negative CD19+ CD27+ memory B cells. The mean number of days until $B$ cells were 


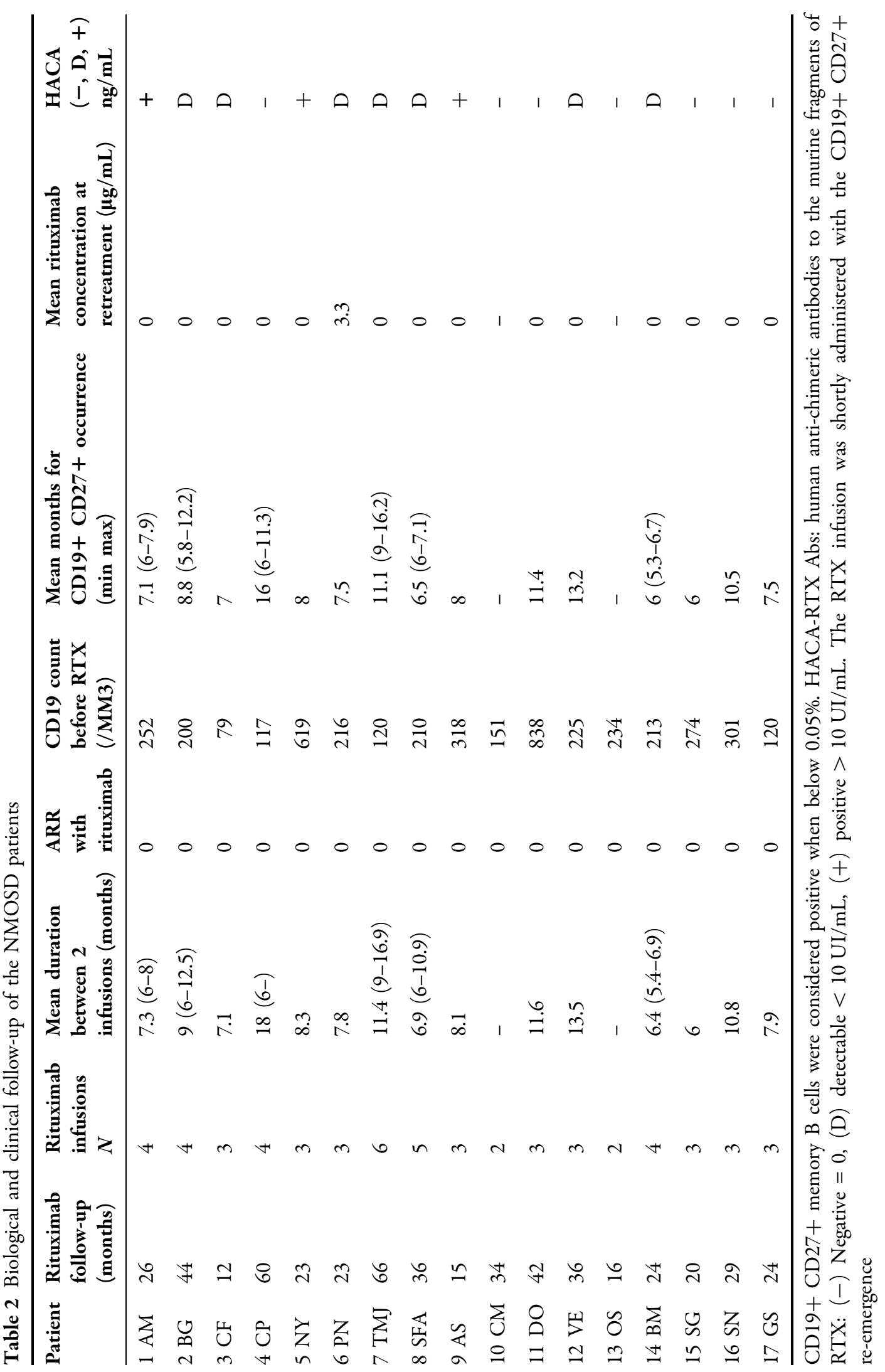



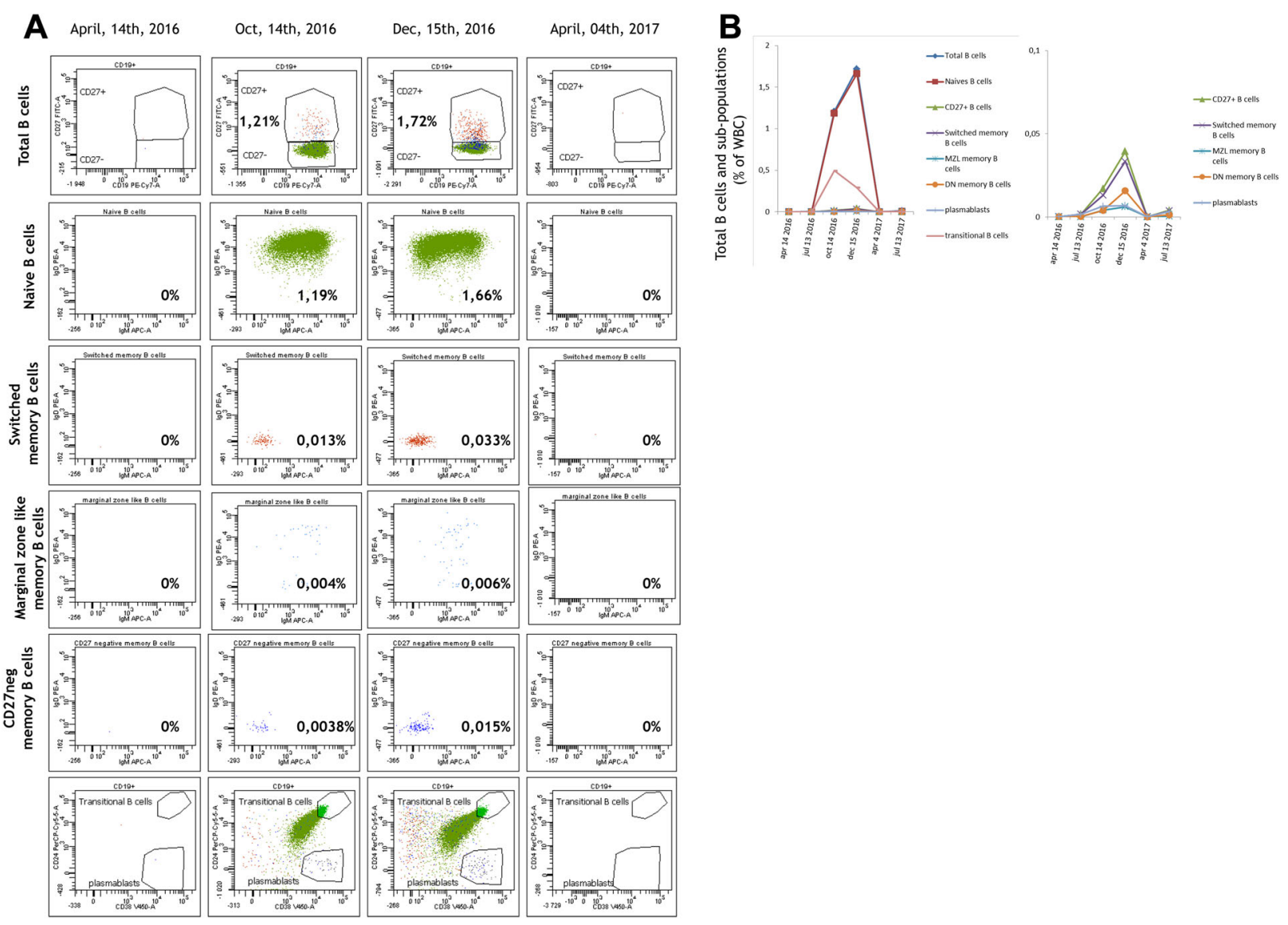

Fig. 1 A typical evolution of memory B cells of a patient (AGS) on follow-up of more than 1 year and the strategy used by the clinical team. a Flow cytometry raw data. The patient had an infusion of rituximab on December 23, 2015. In April 2016 (first row) no B cells were detected. Six months later, on October 2016, B cells represented up to $5.9 \%$ of lymphocytes and $1.21 \%$ of white blood cells. They were mainly composed of naive B cells (in green). CD27-memory B cells, that is the sum of switched and marginal zone memory $\mathrm{B}$ cells (line 3 and 4) represented no more than $0.017 \%$ of WBC. No Rituximab was proposed, but monitoring was shortened. In December

detectable was $15.2(6-36)$ months. In $17 \%$ of patients the total number of $B$ cells measured with the routine test was considered undetectable while total $B$ cells and CD19+ CD27+ memory B cells were positive using the MDR-derived test. In some cases, reemergence of B cells occurred as naïve B cells while memory $B$ cells remained undetectable for several months (Fig. 1b). The mean time of detection for re-emerging
2016, while the total B cells increased only slightly, the memory B cells increased and reached $0.039 \%$ of white blood cells. In addition the population of CD27 negative memory B cells (fifth line) also increased. Infusion of rituximab was proposed to the patient. Four months later, no B cells were detected. Note that over a course of 1 year only one infusion of rituximab was performed. $\mathbf{b}$ The percentage of B cells and the different sub-populations are summarized. Please note that the scale is different for the two charts

CD19+ CD27+ memory B cells was 8.9 months without correlation with total B cell detection. The mean number of lymphocytes analyzed at each visit was $168,434(43,576-278,956)$ cells. The re-emergence of CD19+ CD27+ B cells did not depend on gender, age at diagnosis, body mass index, duration of the disease or history of immunosuppression. Three patients had no memory B cells after few infusions at 12 months 
(AM and SFA) and 20 months (CP) and were qualified as prolonged responders.

\section{Rituximab Concentrations}

All the samples except for two had a detected RTX level when CD19+ CD27+ memory B cells were positive. After RTX infusion, plasmatic levels were negative after about 3-6 months. There was no correlation between the RTX concentration and re-emergence of CD19+ CD27+ memory B cells.

\section{Detection of HACA-RTX Abs}

The patients remained negative during follow-up $(<10)$ excepted for two AQP4 seropositive patients who were HACA-RTX positive respectively at month 15 (NY) and month 12 (AS) and then negative 3 months after RTX infusion (Fig. 2). One NMOSD seronegative patient (DO) was positive on one occasion at 24 months. HACA $(1-3 ;<10 \mathrm{ng} / \mathrm{mL})$ was detected in 45 samples, but did not correlate with RTX infusion,

Patient 1-AS: Ac anti-RTX: $24 \mathrm{ng} / \mathrm{ml}$

Patient 2- NY: Ac anti-RTX: $12 \mathrm{ng} / \mathrm{ml}$

Patient 1

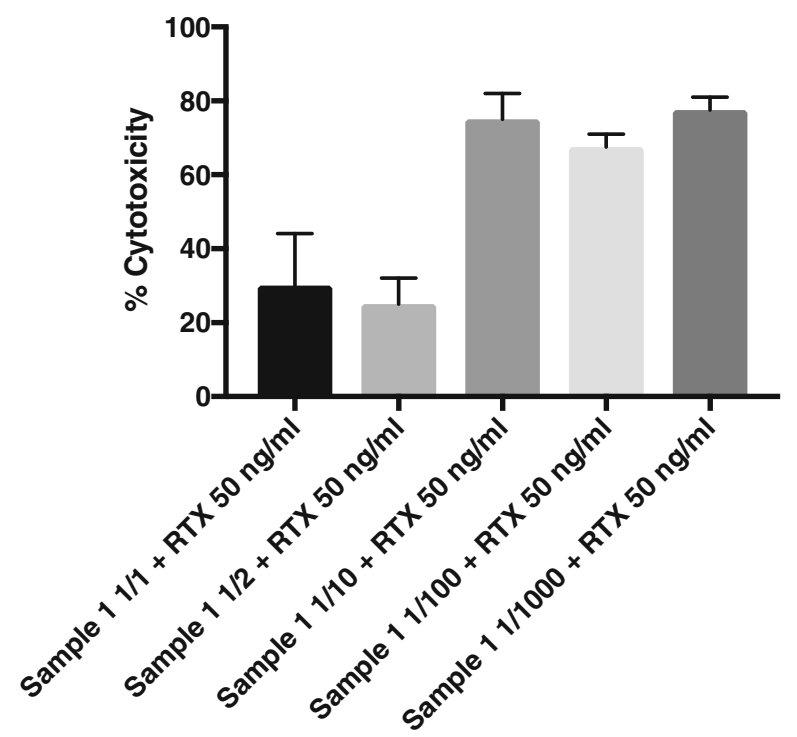

CD19+ cells, CD19+ CD27+ memory B cells reemergence or RTX plasmatic levels. In vitro cytotoxicity assays demonstrated that for one patient (AS) HACA-RTX Abs were neutralizing for RTX activity at $50 \mathrm{ng} / \mathrm{mL}$, but was not for patient NY (Fig. 2). Interestingly, other anti-CD 20 antibodies including ocrelizumab, ofatumumab and obinutuzumab were not neutralized in the patients' sera (data not shown). This result needs to be confirmed on a larger number of samples, but opens therapeutic opportunities for the patients who develop anti-RTX Abs.

\section{Adverse Events}

No serious adverse event due to RTX occurred. Five patients presented grade 1 and two grade 2 adverse event reactions (mild pruritus, requiring symptomatic antihistamic treatment) during the induction course. After the induction treatment, patients had a mean RTX infusion of 1.1 per year (0-2), but only six patients had grade $1 \mathrm{AE}$ (mild headache) due to maintenance infusion.

Fig. 2 Patient AS and NY had anti-RTX antibodies detected in one sample. Patent AS serum neutralized the RTX activity at $50 \mathrm{ng} / \mathrm{ml}$. Patient NY did not have any 


\section{DISCUSSION}

The optimal strategy for maintenance of RTX treatment for patients with NMOSD is yet to be determined. Two different approaches to RTX administration that are not influenced by the AQP4 status can be envisaged. The first is a fixed pretreatment schedule: for example $1 \mathrm{~g}$ d1-d15 every 6 months, as used in Rheumatoid Arthritis (RA). In NMOSD, many team propose $1 \mathrm{~g}$ $\mathrm{d} 1-\mathrm{d} 15$ as an induction and $1 \mathrm{~g}$ d1 every 6 months as maintenance systematically. The second monitors the biological effect of RTX on circulating B cells, renewing RTX infusion at reemergence either of CD19+ B cells or CD19+ CD27+ memory B cells, if re-emergence of biological markers is considered to precede clinical relapse [14-18]. Some studies have shown that it is possible to reduce the posology of RTX without increasing the risk of disease reactivation $[19,20]$. Response to RTX may vary among individuals, especially in the first 2 years after diagnosis [21, 22]. Two different profiles are possible: some patients experience clinical NMO relapse before the sixth month, while other patients are considered as prolonged responders for more than 2 years without maintenance of infusion, underlining the critical importance of identifying reliable biological markers predicting clinical responses $[18,22]$.

Among the biological markers, anti-AQP4 Abs play a key role in diagnosis and are known to be pathogenic [23]. A transient increase in anti-AQP4 Abs at week 2 after the first infusion of RTX was observed before resulting in a decrease [24]. A recent study demonstrated that an increase in anti-AQP4 Abs titers and CD19+ B cells did not always precede relapse, but a reduction in AQP4 Abs titers in the shortand long-term was observed during RTX treatment [25]. Failure on RTX should be suspected if AQP4 Abs levels never decrease during the treatment period [25]. In our study, anti-AQP4 $\mathrm{Ab}$ positivity did not correlate to treatment response.

Since NMO is mainly related to B cell disorders, several studies focused on monitoring the CD19+ B cells level. Indeed, the CD19+ B cells count is dependent on the RTX dose: a recent study demonstrated that the median number of days until a CD19 percentage of $2 \%$ or more was achieved was 140 in the $100 \mathrm{mg}$ dosing arm and 258 days in the $1000 \mathrm{mg}$ dosing arm [26]. After repeating RTX infusion, some patients showed an extended time for repopulation, as some keep the same pattern, and were defined as nonresponders to RTX. However, despite undetectable B cells with a standard technique some patients experienced clinical relapse [26, 27]. One explanation is that $\mathrm{B}$ cells are still present but reside in other locations such as bone marrow or secondary lymphoid organs and so are not circulating and thus not detectable. Another explanation for the unreliability of this biomarker is the lack of sensitivity of the technique. Routine measurements by flow cytometry of lymphocytes populations, including total B cells, usually acquire $2500-5000$ lymphocytes. A recent paper has shown that CD19 mRNA quantification is more sensitive in detecting the CD19+ B cell increment than fluorocytometry, using three-color flow cytometry and acquiring a total number of 100,000 events and is a reliable method to quantify CD19+ circulating B cells in the blood of RTX-treated patients [28].

Finally, only sub-populations of B cells may be critical since recent studies show that the monitoring of CD19+ CD27+ memory B cells, instead of the total B cell count, should be used to tailor administration of RTX [11, 13-18]. Moreover, Cohen et al. observed no linear correlation between total CD19+ B cells and the CD19+/CD27+ B cell counts [18]. In addition, the re-emergence of B cells after RTX therapy is different from one patient to another. Taking these concerns into account, we used in this study an approach derived from minimal residual disease detection in patients with chronic lymphocytic leukemia, which uses multicolor flow cytometry and a number of acquired cells above one million of WBC. This approach allowed detection of total B cells and B cell sub-populations well below $0.01 \%$ of WBC and distinguished naïve and CD27+ memory B cells from total B cells and from different sub-populations of memory B cells. Importantly, these different patient profiles lead to a different therapeutic strategy. While the increase in B cells in some patients 
may concern almost exclusively memory B cell, in others patients it concerns only naïve B cells (defined here as CD19-B cells, CD27- and expressing either surface IgD or IgM). For the former patients, RTX infusions were resumed while no treatment was proposed to the latter patients.

Some papers described RTX non-responding patients or short re-emerging B cells with the production of anti-drug Abs but we did not see this in our case series, even with HACA-RTX positive Abs. The production of IgG human anti-chimeric Abs to the murine fragments of RTX (HACA-RTX Abs) has previously been described with different frequencies in lymphoma and in patients with autoimmune diseases. HACA-RTX Abs production may induce less effective $B$ cell depletion and a rapid drop in RTX levels. A correlation between HACA-RTX Abs and incomplete $\mathrm{B}$ cell depletion has been hypothesized but a direct functional effect of these HACA-RTX Abs has been reported only in one case report, leading to increased infusion side effects and loss of efficacy [29]. Others patients with high titers of HACA-RTX Abs did not experience increased side effects during infusions [30, 31]. The development of HACARTX Abs could be due either to incomplete B cell depletion after the induction course or to RTX with Fc-gamma receptor polymorphisms. HACA-RTX Abs are detected in $25-37 \%$ of relapsing-remitting MS patients treated with RTX and 7-26\% in progressive forms of MS but their clinical significance remains unclear $[32,33]$. The presence of HACA-RTX Abs decreased with an increase in the number of RTX infusions and there was a significant association between both the presence and titers of HACA-RTX Abs and incomplete B-cell depletion, but not with infusion/adverse reactions or clinical outcome, nor with the occurrence of relapse, disability progression or Gadolinium enhancing lesions on brain MRI [34]. NMOSD patients treated with a low dose of RTX seem to be more likely to develop HACA-RTX Abs and need more frequent infusion to be maintained biologically and clinically relapse-free [35]. As RTX is more effective than other immunosuppressive drugs especially azathioprine in NMOSD patients, there is major concern about identifying either an appropriate dosage and prognostic markers of biological or clinical relapse [35-37].

Although we did not directly compare different treatment protocols, none of our 17 patients experienced clinical relapse once RTX was started over a cumulative course of 46 months. These data strongly suggest that an immunologically adjusted infusion protocol is, clinically speaking, not inferior to, e.g., a fixedinterval schedule, while at the same time reducing the number of RTX infusions from 4 to 1.1 per year.

\section{CONCLUSIONS}

The data presented here indicate that when RTX is used as therapy in NMOSD the patients should be followed closely by monitoring CD19+ CD27 B memory cells to ensure both adequate immunological responses and tailoring RTX administration.

NMOSD patients can develop HACA-RTX Abs but can stay relapse-free with undetectable RTX concentrations and no CD19+ CD27 B memory cells. None of our patients relapsed with a decrease in the infusion frequency compared with the most commonly used schedule of four infusions/year. The use of the level of CD19+ B cells to decide whether or not the patients should be treated is not reliable and might be replaced by the monitoring of memory B cells. Whether one of the different memory sub-populations could be a better predictive value than the whole memory $\mathrm{B}$ cell population remains to be determined with a larger number of patients.

\section{ACKNOWLEDGEMENTS}

Funding. No funding or sponsorship was received for this study or publication of this article.

Authorship. All named authors meet the International Committee of Medical Journal Editors (ICMJE) criteria for authorship for this article, take responsibility for the integrity of 
the work as a whole, and have given their approval for this version to be published.

Disclosures. C Lebrun, M Cohen, M Rosenthal, S Bresch, S Benzaken, R Marignier, B Seitz Polski, M Ticchioni have nothing to disclose.

Compliance with Ethics Guidelines. This article is based on previously conducted studies and does not contain any studies with human participants or animals performed by any of the authors.

Data Availability. All data generated or analyzed during this study are included in this published article/as supplementary information files.

Open Access. This article is distributed under the terms of the Creative Commons Attribution-NonCommercial 4.0 International License (http://creativecommons.org/licenses/ by-nc/4.0/), which permits any noncommercial use, distribution, and reproduction in any medium, provided you give appropriate credit to the original author(s) and the source, provide a link to the Creative Commons license, and indicate if changes were made.

\section{REFERENCES}

1. Wingerchuk DM, Banwell B, Bennett JL, Cabre P, Carroll W, Chitnis T, de Seze J, et al. International consensus diagnostic criteria for neuromyelitis optica spectrum disorders. Neurology. 2015;85:177-89.

2. Jarius S, Wildemann B. The history of neuromyelitis optica. J Neuroinfl. 2013;10:8.

3. Zekeridou A, Lennon VA. Aquaporin-4 autoimmunity. Neurol Neuroimmunol Neuroinflam. 2015;2(4):e110.

4. Trebst C, Jarius S, Berthele A, Paul A, Schippling S, Wildemann $B$, et al. Update on the diagnosis and treatment in Neuromyelitis Optica. Recommandations of the NMO study group (NEMOS). J Neurol. 2014;261(1):1-16.

5. Collongues N, de Seze J. An update on the evidence for the efficacy and safety of rituximab in the management of neuromyelitis optica. Ther Adv Neurol Disord. 2016;9:180-8.

6. Cree B, Lamb S, Morgan K, Chen A, Waubant E, Genuine C. An open label study of the effects of rituximab in neuromyelitis optica. An open label study of the effects of rituximab in neuromyelitis optica. Neurology. 2005;64:1270-2.

7. Zéphir H, Bernard-Valnet R, Lebrun C, Outteryck O, Audoin B, Bourre B, Pittion S, et al. Rituximab as first-line therapy in neuromyelitis optica: efficiency and tolerability. J Neurol. 2015;262:2329-35.

8. Collongues N, Brassat D, Maillart E, Labauge P, Ouallet JC, Carra-Dalliere C, Moreau T, et al. Efficacy of rituximab in refractory neuromyelitis optica. Mult Scler. 2016;22:955-9.

9. Damato V, Evoli A, Lorio R. Efficacy and Safety of Rituximab Therapy in Neuromyelitis Optica Spectrum Disorders: a Systematic Review and Metaanalysis. JAMA Neurol. 2016;73:1342-8.

10. Wingerchuk DM, Lennon VA, Pittock SJ, Lucchinetti CF, Weinshenker BG. Revised diagnostic criteria for neuromyelitis optica. Neurology. 2006;66:1485-9.

11. Waters P, Reindl M, Saiz A, Schanda K, Tuller F, Kral $\mathrm{V}$, Nytrova $\mathrm{P}$, et al. Multicentre comparison of a diagnostic assay: aquaporin-4 antibodies in neuromyelitis optica. J Neurol Neurosurg Psychiatry. 2016;87(9):1005-15.

12. Lebrun C, Bourg V, Bresch S, Cohen M, RosenthalAllieri MA, Desnuelle C, Ticchioni M. Therapeutic target of memory B cells depletion helps to tailor administration frequency of rituximab in myasthenia gravis. J Neuroimmunol. 2016;298:79-81.

13. Seitz-Polski B, Dahan K, Debiec H, Rousseau A, Lochouarn M, Ticchioni M, Rosenthal MA et al. Residual serum rituximab levels and neutralizing anti-rituximab antibodies may predict remission and relapse of PLA2R1-related membranous nephropathy. (Submitted).

14. Kim SH, Huh SY, Lee SJ, Joung A, Kim HJ. A 5-year follow-up of rituximab treatment in patients with neuromyelitis optica spectrum disorder. JAMA Neurol. 2013;70:1110-7.

15. Kim SH, Jeong HI, Hyun J, Joung A, Jo H, Hwang $\mathrm{SH}$, Yun S, et al. Treatment outcomes with rituximab in 100 Patients with neuromyelitis optica: influence of FCGR3A polymorphisms on the therapeutic response to rituximab. JAMA Neurol. 2015;72:989-95.

16. Kim SH, Kim W, Li XF, Jung IJ, Kim HJ. Repeated treatment with rituximab based on the assessment 
of peripheral circulating memory B cells in patients with relapsing neuromyelitis optica over 2 years. Arch Neurol. 2011;68:1412-20.

17. Romero G, Ticchioni M, Cohen M, Rosenthal-Allieri MA, Mondot L, Lebrun-Frénay C. Neuromyelitis optica: Contribution of therapeutic responses markers monitoring in patients given rituximab. Rev Neurol. 2015. https://doi.org/10. 1016/j.neurol.2015.12.004.

18. Cohen M, Romero G, Bas J, Ticchioni M, RosenthalAllieri MA, Lacroix R, Brunet C, et al. Monitoring CD27+ memory B-cells in neuromyelitis optica spectrum disorders patients treated with rituximab: results from a bicentric study. J Neurol Sci. 2017;373:335-8.

19. Yang CS, Yang L, Li T, Zhang D, Jin W, Li M, Su N, et al. Responsiveness to reduced dosage of rituximab in Chinese patients with neuromyelitis optica. Neurology. 2013;81:710-3.

20. Chay J, Donovan P, Cummins L, Kubler P, Pillans P. Experience with low-dose rituximab in off-label indications at two tertiary hospitals. Intern Med J. 2013;43:871-82.

21. Lindsey JW, Meulmester KM, Brod SA, Nelson F, Wolinsky JS. Variable results after rituximab in neuromyelitis optica. J Neurol Sci. 2012;317(1-2):103-5.

22. Perumal JS, Kister I, Howard J, Herbert J. Disease exacerbation after rituximab induction in neuromyelitis optica. Neuro Neuroimmunol. 2015;2(1):e61.

23. Lennon VA, Wingerchuk DM, Kryzer TJ, Pittock SJ, Lucchinetti CF, Fujihara K, Nakashima I, et al. A serum autoantibody marker of neuromyelitis optica: distinction from multiple sclerosis. Lancet. 2004;364:2106-12.

24. Nakashima I, Takahashi T, Cree BA, Kim HJ, Suzuki $\mathrm{C}$, Genain CP, et al. Transient increases in antiaquaporin-4 antibody titers following rituximab treatment in neuromyelitis optica, in association with elevated serum BAFF levels. J Clin Neurosci. 2011;18(7):997-8.

25. Valentino P, Marnetto F, Granieri L, Capobianco M, Bertolotto A. Aquaporin-4 antibody titration in NMO patients treated with rituximab: a retrospective study. Neurol Neuroimmunol Neuroinflamm. 2016;4(2):e317.

26. Greenberg BM, Graves D, Remington G, Hardeman P, Mann M, Karandikar N, Stuve O, et al. Rituximab dosing and monitoring strategies in neuromyelitis optica patients: creating strategies for therapeutic success. Mult Scler. 2012;18:1022-6.
27. Pellkofer HL, Krumbholz M, Berthele A, Hemmer B, Gerdes LA, Havla J, Bittner R, et al. Long-term follow-up of patients with neuromyelitis optica after repeated therapy with rituximab. Neurology. 2011;76:1310-5.

28. Marnetto F, Granieri L, Valentino P, Capobianco M, Pautasso M, Bertolotto A. CD19 mRNA quantification improves rituximab treatment-to-target approach: a proof of concept study. J Neuroimmunol. 2014;277(1-2):127-33.

29. Cartron G, Blasco H, Paintaud G, Watier H, Le Guellec C. Pharmacokinetics of rituximab and its clinical use: thought for the best use? Crit Rev Oncol/Hematol. 2007;62:43-52.

30. Lunardon L, Payne AS. Inhibitory human anti-chimeric antibodies to rituximab in a pemphigus patient. J Allergy Clin Immunol. 2012;130(3):800-3.

31. Tahir H, Rorher J, Bhatia A, Wegener WA, Isenberg DA. Humanized anti-CD20 monoclonal antibody in the treatment of severe resistant systemic lupus erythematosus in a patient with antibodies against rituximab. Rheumatology. 2005;44:561-2.

32. Hauser SL, Waubant E, Arnold DL, Vollmer T, Ante J, Fox RJ, Bar-Or A, et al. B-cell depletion with rituximab in relapsing-remitting multiple sclerosis. N Engl J Med. 2008;358:676-88.

33. Hawker K, O'Connor P, Freedman MS, Calabresi PA, Antel J, Simon J, Hauser S, et al. Rituximab in patients with primary progressive multiple sclerosis: results of a randomized double blind placebocontrolled multicenter trial. Ann Neurol. 2009;66:460-71.

34. Dunn N, Juto A, Ryner M, Manouchehrinia A, Piccoli L, Fink K, Piehl F, Fogdell-Hahn A. Rituximab in multiple sclerosis: Frequency and clinical relevance of anti-drug antibodies. Mult Scler 2017. https:// doi.org/10.1177/1352458517720044.

35. Li LT, Zhang LJ, Yang QX, Zhang CS, Li YJ, et al. Anti-Rituximab antibody in patients with NMOSDs treated with low dose Rituximab. J Neuroimmunol. 2018;316:107-111. https://doi.org/10.1016/j. jneuroim.2017.12.021.

36. Stellmann JP, Krumbholz M, Friends T, Gahlen A, Borisow N, Fisher K, Hellwig $\mathrm{K}$, et al. Immunotherapies in NMOSD: efficacy and predictors of response. J Neurol Neurosurg Psychiatry. 2017;88(8):639-47.

37. Nikoo Z, Badihian S, Shaygannejad V, Asgari N. Comparison of the efficacy of azathioprine and rituximab in neuromyelitis optica spectrum disorder: a randomized clinical trial. J Neurol. 2017. https://doi.org/10.1007/s00415-017-8590-0. 